\title{
The Use of Teaching Aids in Increasing Student Motivation at Elementary School
}

\author{
Gamar Al Haddar ${ }^{1}$, Nurul Azmi² \\ 1,2 Widya Gama Mahakam University \\ Email: gamarhaddar19@gmail.com¹, Azmin4241@gmail.com²
}

\begin{abstract}
This study aims to determine the role of teaching aids by teachers in increasing student motivation at Elementary School 027 Samarinda Ulu in the 2019/2020 learning year. The technique of determining the subject used in this research was purposive sampling, and the data analysis techniques used data collection, data selection, data presentation, and conclusion drawing. The type of triangulation used is source triangulation.

The result of the research is that the teacher uses teaching aids that are twodimensional and three-dimensional. The increase in learning motivation for grade 1B students is good, and this is evidenced by the willingness of students to bring props, increasing the enthusiasm of students to improve their lack of grades, increasing the focus of student learning, the enthusiasm of students in demonstrating the use of teaching aids directly.
\end{abstract}

Keywords: Teaching Aids, Learning Motivation

\section{INTRODUCTION}

Education is a way of obtaining knowledge consciously and planned. Education is classified into three, namely formal education, non-formal education, and informal education. Formal education, namely participating in the teaching and learning process in schools structured and tiered, consists of primary education, secondary education, and higher education. Non-formal education is obtained from the learning process outside the school environment. Meanwhile, informal education is obtained from within the family and the environment, such as courtesy, morals, ethics, and others 
(Triyono, 2019). Everyone needs education to free himself or a nation from the pain of ignorance, poverty, and backwardness (Hendratmoko, 2018)

Education in Indonesia currently uses the 2013 curriculum is identical to thematic learning and integrated learning. The concept of thematic learning is to use a theme to connect several subjects to add meaningful knowledge and experience to students (Setiadi, 2016). One theme is divided into four subthemes, and one sub-theme is divided into six lessons. Teachers are required to be creative in developing the lessons on the theme so that learning is not boring (Prastowo, 2019)

A teacher's role, especially in formal education, is to educate, teach, guide, direct, motivate, train, assess, and evaluate students (Pianda, 2018). Teachers must have skills in selecting and using teaching aids in delivering learning material. Teaching aids as a tool for teachers in delivering material so that students do not get bored when participating in teaching and learning activities (Purbaningsih, 2017).

The use of media or props can stimulate the focus of student learning. Props are objects that are used to help the teaching and learning process. The use of teaching aids in the learning process can make teacher explanation methods more varied. (Hartati, 2010) The use of teaching aids can make students more active in participating in learning activities, demonstrate props and enthusiasm for learning (Purbaningsih, 2017) argues that the use of teaching aids can help teachers in delivering subject matter, can create a pleasant learning atmosphere for students, can motivate students to take part in learning.

Teaching aids aim to increase student motivation and learning outcomes through concrete teaching aids (Rahayu, 2018). The use of letter 
card props improves student motivation and learning outcomes (Sarimani, 2016). Besides that, the use of graphic props can also increase student learning motivation (Nomleni, 2018)

Motivation to learn is a desire that arises from within and from outside a person. The strength and weaknesses of student participation in learning depend on how strong their motivation to learn. The stronger the student's motivation to learn, the stronger the effort and participation made in learning. Conversely, if the motivation to learn is weak, the effort and participation in learning will be weaker. Learning motivation is very important to be improved, and this requires the role of various elements involved in the learning process both from students, teachers, and the learning environment. If teachers can create learning situations that exploit students 'abilities, student perceptions that learning is a boring learning activity will be lost, and learning objectives will be easier to achieve (Kusiah, 2015).

Based on the observations described above, the researcher is interested in researching how teaching aids in increasing Class 1B students' motivation at the elementary school 027 Samarinda Ulu.

\section{METHODS}

This research was conducted to determine the role of teaching aids on student learning motivation. This type of research used in this research is qualitative research. Qualitative research is descriptive, and the nature of the research is natural. This research was conducted at Elementary School 027 Samarinda Ulu, Pramuka Street, Samarinda Ulu District, Samarinda City, East Kalimantan Province. This research was conducted in the even semester of the 2019/2020 learning year. 
In this study, the research subjects were class 1B teachers, five students from $1 \mathrm{~B}$ class, and five parents of students from $1 \mathrm{~B}$ class. The sample selection in this research was using the purposive sampling technique. Purposive sampling technique is a technique of sampling data sources with specific considerations that the person know best what we expect (Sugiyono, 2016)

The subject's criteria to be researched in class $1 \mathrm{~B}$ teachers who had used teaching aids when teaching. The criteria for student subject are students who participate in teaching and learning activities in class $1 \mathrm{~B}$. The criteria for parent's student are parents who understand their child's personality.

The data collection techniques are interviews and documentation. There are four analysis techniques in qualitative research: data collection, data selection, data presentation, and concluding. Data collection tools using interview guidelines and document guidelines. Instrument validity testing is done by examining the validity of the content and validity of the construct. The triangulation used in this study is the triangulation of sources (Sukardi, 2002)

\section{RESULT}

Based on an interview with Mrs. JL as a grade 1B teacher at Elementary School 027, Samarinda Ulu on Monday, April 27, 2020, in the learning process in class $1 \mathrm{~B}$ using visual aids such as pictures. As for the lessons of Cultural Arts and Crafts, teachers sometimes use audio props such as loudspeakers. Audiovisual props such as videos are also used, but only Islamic teachers have applied these props. The props most often used be pictures because they are not only exciting but also easy to make. 
Based on interviews with a class 1B student named AR at SDN 027 Samarinda Ulu on Tuesday, April 28, 2020, teachers often use picture props and have also used audio props, namely speakers but never use video or films. The teaching aid most often used by teachers, is pictured. This is the same as the results of interviews with FW students on Wednesday, April 29, 2020. Teachers teach using the enlarged image and writing props and have also used audio props, namely speakers, but audio-visual props such as videos or films have never been. The teaching aids most often used by teachers when teaching pictures.

This is also the same as the results of interviews with ZP students on Thursday, April 30, 2020, that teachers teach using picture props, speakers are also ordinary but not often. The teaching aids most often used by the teacher are pictures. This is also the same as the results of interviews with AY students on Thursday, April 30, 2020, that teachers often use picture props and have also used speakers. Likewise, in interviews with LV students on Thursday, April 30, 2020, teachers often teach using picture props and use speakers. The props most often used be pictures.

Based on the results of the interviews and review of the documents above. It can be concluded that the teacher uses visual aids such as pictures, origami paper, number cards, and has also used speakers when teaching in class. The teaching aids most often used by teachers when teaching are pictures

\section{Benefits of Teaching Aids}

Based on the results of an interview with Mrs. JL as grade 1B teacher at Elementary School 027 Samarinda Ulu on Monday, April 27, 2020, that the use of audio or visual aids in learning is quite useful, but the use of audio- 
visuals is more effective if the facilities are supportive. Teaching aids can make it easier for the teacher to explain the material to students, but first graders have a higher play than learning, writing, and reading. Therefore the teacher must innovate in making props so that the abstract can be explained with concrete objects to play, but they are learning, so students do not feel bored.

Based on interviews with AR students on Tuesday, April 28, 2020, information was obtained that if the teacher taught using teaching aids, he would become more focused and understand learning. Likewise, the results of interviews with FW students on Wednesday, April 29, 2020, when the teacher taught using teaching aids, he felt it was easier and understood what was being learned.

This is also supported by the results of interviews with ZP students on Thursday, April 30, 2020, namely, if the teacher teaches using teaching aids, learning will be more fun and easy to understand. This was also reinforced by the results of an interview with a student named AY on Thursday, April 30, 2020, namely that if the teacher taught using teaching aids, he felt it was easier to understand and more focused. Likewise, the results of an interview with an LV student on Thursday, April 30, 2020, that the teacher taught using teaching aids, he felt more fun, easy to understand the lesson, and more focused.

Based on the results of the interview above. It can be concluded that the use of teaching aids in the teaching and learning process can make learning more effective, easy to understand because you can directly see the example intended by the teacher. 


\section{Motivation to Learn}

Based on the results of an interview with Mrs.JL, a grade 1B teacher at Elementary School 027 Samarinda Ulu, on Monday, April 27, 2020, that the teacher had made a complete lesson schedule. In general, students obey school regulations. If there are students who get fewer grades, then he tries to improve the lower scores. Students are also enthusiastic about bringing props when asked by the teacher to bring them seeds and origami paper. Not all students can seriously participate in learning, but when the teacher uses teaching aids, they are more motivated to focus on learning. In general, grade 1B students have a high sense of competence with their peers to get the best results in class. Grade 1 students are pleased to get praise, so they provide feedback in rewards for students who excel. The rewards are often given in speech and body language, such as the words " excellent, " " smart, " and " giving applause and thumbs up. Students desire to go to school, there are diligent students, and some are not diligent. In general, students in grade 1B who diligent can be categorized as students who diligently go to school.

Based on the results of interviews with AR, ZP, FW, AY, and LV students. They recorded the teacher's lesson schedule and obeyed rules such as going to class on time. They improve their learning results if they get a score below average.

Based on the results of interviews with AR students on Tuesday, April 28, 2020, it was strengthened by the results of the FW interview on Wednesday, April 29, 2020. It was strengthened by the results of interviews with ZP students on Thursday, April 30, 2020, and also strengthened by the results of interviews with AY students on Thursday, April 30, 2020, was even strengthened by the results of interviews with LV students on Thursday, April 
30,2020 , that the teacher provided teaching aids, some students brought each one from homes, such as seeds and origami paper. All students bring teaching aids ordered by the teacher.

Based on interviews with class 1B students named AR, ZP, FW, AY, and $\mathrm{LV}$, they are more serious about participating in learning activities when using teaching aids. The seriousness they do by focusing on paying attention to the teacher's explanation and concentrating on learning activities. Based on the interview results, it was found that they were always trying to get the best results. The teacher gives praise when there are students who get the best results. His compliments are in the form of body language, such as applause and thumbs up. Grade 1B students are enthusiastic about coming to school and diligent in taking notes on the subject matter explained by the teacher

This is the same as the results of interviews with parents of students named Mrs. AT, Mrs. ER, Mrs. WI, and Mrs. SI on Wednesday, April 29, 2020, that their children have high aspirations to become teachers, doctors, and others. His child's efforts to realize that is to repeat the lessons that have been learned in school. If it gets bad results, he tries to fix it. They also always bring props from home when the teacher asks them to be serious in participating in classroom learning activities.

Based on the results of the document review found by researchers regarding student learning motivation. It was seen from the absence of students who were always present unless they were sick. Based on the interview results and review of the documents above, it was concluded that grade $1 \mathrm{~B}$ students had a good motivation. 


\section{DISCUSSION}

Based on the results of the interviews and document review above, it can be concluded that the types of teaching aids used by the teacher are twodimensional and three-dimensional visual types, namely pictures, origami paper, number cards, and types of audio props. Following the theory (Sumiharsono H., 2017), teaching aids are devices that can be seen by the eye and heard by the ear (Pane, 2017). The use of teaching aids by the teacher can increase student motivation. As explained in theory (Solichah, 2014) that the benefits of teaching aids in learning can make the teaching and learning process more motivated. Teachers and students, especially students, will feel happy, aroused, interested, and interested and willing to learn.

The learning motivation of grade $1 \mathrm{~B}$ students is stated to be good. This can be proven by students' willingness to provide teaching aids from home, such as carrying origami paper and carrying seeds. Besides, students' efforts to improve unsatisfactory grades were evidenced by students asking questions about material that had not been understood and practicing doing questions given by the teacher. As for the focus of students during learning (Balfanz, 2009). It was proven by students listening, paying attention, not talking or playing much during learning, and students who had material notes. Students' enthusiasm in learning is then evidenced by the presence of good students and students' enthusiasm in demonstrating it directly. This is indicated by the results of collage work and flat shapes from origami paper made by students.

Student behavior above that reflects a motivated attitude is reinforced by the theory (Darmadi, 2017) that individual behavior with learning motivation characteristics can be seen from students' seriousness in learning. Students' desire to provide the tools or learning resources needed, the seriousness of 
students in listening. Teacher's explanation, efforts to get the best results, and enthusiasm of students in following lessons.

Research conducted by researchers has proven that the use of teaching aids by teachers can increase student motivation. This is evidenced by students' willingness to bring props, students' efforts to improve poor grades. Students are more focused during learning and students who are enthusiastic in learning and demonstrate the use of teaching aids directly. This is following research (Purbaningsih, 2017) with the title Use of Teaching Aids to Increase Motivation and Mathematics Learning Outcomes of Class IV Students of SD Negeri 03 Gondangrejo in the 2017 academic year. That the use of teaching aids can increase student learning motivation from the characteristics of learning behavior. The students' enthusiasm for learning, dare to answer questions in front of the class, solve problems properly and correctly, are resilient, do not give up easily, and diligently learn.

This study's results are also following the research (Widiastuti, 2016) entitled the use of folding paper teaching aids to increase student motivation and learning outcomes in mathematics in the fraction concept of class iv at Elementary School Negeri 1 Harapan Rejo for the 2015/2016 Academic Year. Folding paper props can increase student motivation and learning outcomes. The increase in student motivation can be seen from students' interest and attention towards learning, students' enthusiasm to do learning tasks, students' responsibility in doing assignments, and the reactions or responses shown by students to the assignments given by the teacher. 
Mudarrisa: Jurnal Kajian Pendidikan Islam, Vol. 12, No. 2, 2020

\section{CONCLUSION}

Based on the results of the discussion regarding the use of teaching aids in increasing student motivation at Elementary School 027 Samarinda, it was found that the teacher used teaching aids that were two-dimensional and threedimensional. The increase in learning motivation of class 1B students is good. This is evidenced by students' willingness to bring props, students' enthusiasm in increasing the value that is lacking, the increase in student learning focus, and the enthusiasm of students indirectly demonstrating the teaching aids.

\section{REFERENCES}

Balfanz, R. (2009). Putting middle grades students on the graduation path. Policy and practice brief.

Darmadi. (2017). Pengembangan Model Metode Pembelajaran dalam Dinamika Belajar Siswa. Yogyakarta: Budi Utama.

Hartati. (2010). Pengembangan Alat Peraga Gaya Gesek Untuk Meningkatkan Keterampilan Berpikir Kritis Siswa SMA. Jurnal Pendidikan Fisika Indonesia, 128-132.

Hendratmoko, T. K. (2018). Tujuan Pembelajaran Berlandaskan Konsep Pendidikan Jiwa Merdeka Ki Hajar Dewantara. JINOTEP (Jurnal Inovasi dan Teknologi Pembelajaran): Kajian dan Riset Dalam Teknologi Pembelajaran, 152-157.

Kusiah. (2015). Upaya meningkatkan Motivasi Belajar Matematika dengan Media Gambar Siswa Kelas 1 SDN Kajen Margoyoso Pati Tahun 2014/2015. Metrologia, 116.

Maesaroh, S. (2013). Peranan Metode Pembelajaran Terhadap Minat dan Prestasi Belajar Pendidikan Agama Islam. Jurnal Kependidikan, 150-168. 
Nomleni, F. \&. (2018). Pengembangan Media Audio Visual dan Alat Peraga dalam Meningkatkan Pemahaman Konsep dan Pemecahan Masalah. Jurnal Pendidikan Dan Kebudayaan, 219-230.

Pane, A. \&. (2017). Belajar dan pembelajaran. Fitrah: Jurnal Kajian Ilmu-Ilmu Keislaman, 333-352.

Pianda, D. (2018). Kinerja Guru: Kompetensi Guru, Motivasi Kerja dan Kepemimpinan Kepala Sekolah. Jawa barat: CV Jejak.

Prastowo, A. (2019). Analisis Pembelajaran Tematik. Jakarta: Kencana.

Purbaningsih, T. (2017). Penggunaan Alat Peraga Untuk Meningkatkan Motivasi dan Hasil Belajar Matematika Siswa Kelas IV SD Negeri 03 Gondangrejo Tahun Pelajaran 2017 . Doctoral dissertation, IAIN Metro.

Rahayu, S. (2018). Penggunaan Alat Peraga Dengan Pembelajaran Langsung Dalam Meningkatkan Motivasi Mengajar Guru Di Sd Negeri 010 Pagaran Tapah. JURNAL PAJAR (Pendidikan dan Pengajaran), 1016.

Rahman, H. S. (2002). Konsep Dasar Pendidikan Anak Usia Dini. Yogyakarta: PGTKI Press.

Sagala, S. (2010). Konsep dan Makna Pembelajaran: Untuk Membantu Memecahkan Problematika Belajar dan Mengajar. Bandung: Alfabeta.

Sarimani. (2016). Upaya Meningkatkan Motivasi dan Hasil Belajar Siswa Pada Materi Membaca Menggunakan Alat Peraga Kartu Huruf Dengan Penerapan Tematik di Kelas I. Jurnal Konseling dan Pendidikan.

Setiadi, H. ( 2016). The Implementation Of Assessment In The Curriculum 2013. Jurnal Penelitian dan Evaluasi Pendidikan, Volume 20, No 2, Desember 2016 (166-178).

Solichah, I. (2014). Alat Peraga untuk Pelajar Tunarungu Penggunaan Bentuk Dua Dimensi Bangun Datar pada Siswa Tunarungu. Media Guru. 
Strauss, A., \& Corbin, J. (2003). Dasar-dasar Penelitian Kualitatif. Yogyakarta: Pustaka Pelajar.

Stubbs, S. (2002). Pendidikan Inklusif: Ketika hanya ada sedikit sumber, trans. Susi Septaviana R.

Sugiyono. (2016). Metode Penelitian Kuantitatif, Kualitatif dan RED. Bandung: Alfabeta.

Sukardi. (2002). Metodologi Penelitian Pendidikan: Kompetensi dan Prakteknya. Jakarta: Bumi Aksara.

Sumiharsono, R. (2017). Media Pembelajaran: Buku Bacaan Wajib Dosen, Guru dan Calon Pendidik. Jawa Timur: Pustaka Abadi.

Tarihoran, E. (2018). Profesi Guru Dalam Tantangan, Harapan dan Kenyataan. SAPA-Jurnal Kateketik dan Pastoral, 100-114.

Triyono, U. (2019). Kepemimpinan Transformasional dalam Pendidikan: (Formal, Non Formal, dan Informal). Yogyakarta: CV. Budi Utama.

Widiastuti, A. (2016). Penggunaan Alat Peraga Kertas Lipat Untuk Meningkatkan Motivasi dan Hasil Belajar Siswa Mata Pelajaran Matematika Pada Konsep Pecahan Kelas IV di SD Negeri 1 Harapan Rejo Tahun Pelajaran 2015/2016. FKIP PGMI STAIN Jurai Siwo.

Zayadi, A., \& Majid, A. (2005). Tadzkirah Pendidikan Agama Islam (PAI) Berdasarkan Pendekatan Kontekstual. Jakarta: Raja Grafindo Persada. 